\title{
Variability and trait relationships among finger millet accessions in Uganda
}

\author{
L. Owere ${ }^{1,2}$, P. Tongoona ${ }^{1}$, J. Derera ${ }^{1}$ and N. Wanyera ${ }^{3}$ \\ ${ }^{1}$ African Centre for Crop Improvement, School of Agricultural, Earth and Environmental Sciences, \\ College of Agriculture, Engineering and Science University of KwaZulu Natal, Private Bag X01, \\ Scottsville, Pietermaritzburg 3209, Republic of South Africa \\ ${ }^{2}$ Buginyanya Zonal Agricultural Research and Development Institute P. O. Box 1356, \\ Mbale, Uganda \\ ${ }^{3}$ National Semi-Arid Resources Research Institute, Serere, Private Bag, Soroti, Uganda
}

Author for correspondence: owerepaya@yahoo.com, labowere@gmail.com

\begin{abstract}
Finger millet (Eleusine coracana (L.) Gaertn]) is a vital component in the farming systems of many parts of Uganda with limited information on variability, heritability and trait association in the country. The objective of this study was to assess the variability, heritability and trait association of finger millet to determine the genetic potential for future use in breeding programmes. A total of 100 accessions were evaluated for morpho-agronomic characters in a $10 \times 10$ lattice design at NaSARRI and Ikulwe in Uganda for two seasons. Analysis of variance revealed mean squares of the genotypes were significant for all the traits, with days to $50 \%$ flowering showing the least coefficient of variation and the highest leaf blast severity. Heritability estimates ranged from $\mathbf{7 . 3 9 \%}$ for threshing percentage to $\mathbf{6 8 . 4 \%}$ for head blast severity; whereas values of expected genetic advance varied from $\mathbf{2 . 0 0}$ to $\mathbf{7 9 . 9 \%}$ for threshing percentage and head blast severity, respectively. High heritability and genetic advance estimates were exhibited for head blast severity, head blast incidence, productive tillers plant $^{-1}$ and grain yield. When the significant correlations were decomposed by path analysis, it revealed that, in determining yield, the most important traits were grain mass head ${ }^{-1}$, tillering ability and reaction to head blast disease. Overall the result revealed existence of high variability for the traits studied in the finger millet accessions which can be utilised in genetic improvement.
\end{abstract}

Key words: Eleusine coracana, head blast, heritability

\section{Introduction}

Finger millet (Eleusine coracana (L.) Gaertn) is a member of the Chloriroidea family and sub-family Poaceae believed to have originated from eastern Africa (National Research Council (NRC), 1996), its centre of origin and diversification 
(NRC, 1996; Bezaweletaw et al., 2006). It is an important allo-tetraploid cereal crop, widely cultivated in the arid and semi arid regions of the world. Being rich in protein, iron and calcium, finger millet serves as an important staple food for rural populations in developing tropical countries where calcium deficiency and anaemia are widespread (Babu et al., 2013). In Uganda, finger millet is the second most important cereal after maize; cultivated in over 470,000 ha, producing over 850,000 metric tonnes year ${ }^{-1}$ (FAOSTAT, 2012). The cultivars grown include mostly landraces, adapted to the various local conditions and a few improved and introduced materials.

In terms of research, however, this important nutri-cereal has been largely neglected and often categorised as an orphan crop (Wanyera, 2007; Kumar and Pande, 2010) mainly grown by subsistence farmers who employ their own methods of selection to preserve and try to improve their germplasm. These farmers grow mainly landraces whose yields are often low, in most cases less than one metric tonne ha-1 (Okwadi, 2007). A few new varieties have been released (Wanyera, 2007) and disseminated in some parts of the country, with varying degrees of success. Replacement of landraces with modern pure-line cultivars may, however, reduce the genetic variation in the cropping system. Nonetheless, some germplasm collection and maintenance has been carried out by the National Semi Arid Resources Research Institute (NaSARRI), though not fully complete and with some challenges, a number of accessions are being preserved at the institute.

Reports indicate that there is high trait variability available, but despite the high range of availability of materials and urgent need to improve finger millet productivity through genetic manipulation, little is known about the Ugandan germplasm in terms of variability, major traits, trait associations and the potential usefulness of the individual accessions being maintained. Bezaweletaw et al. (2006) indicated that investigating and identifying plants for available variation in the breeding material, is the first step of a successful plant breeding and crop improvement programme. Studies have not been conducted in Uganda to measure variability in finger millet collections based on morphological and agronomic traits. High variability in major traits have been observed in finger millet from previous studies elsewhere (Prasad Rao et al., 1994; Bezaweletaw et al., 2006; Oduori 2008) suggesting broad diversity to be apparent among finger millet germplasm that were studied in Kenya, Ethiopia and India, respectively. This would, therefore, provide ample opportunities for genetic improvement of the crop through selection directly from the available germplasm or traits recombination through intra-specific hybridisation of desirable traits.

Grain yield is a complex character, and is considered as the ultimate product of its components. Hence, selection of superior genotypes based on grain yield is difficult due to the integrated structure of plants in which most of the characters are interrelated and governed by many genes (Falconer and Mackay, 1996). This necessitates a thorough knowledge on the nature of relationships prevalent between contributory characters and grain yield and the extent of genetic variability (Bezaweletaw et al., 2007). Besides, determination of the interrelationships between various agronomic characters, and their direct and indirect effects on grain yield may provide a clue for 
improving the productivity of the crop, and a pre-requisite to plan a meaningful breeding programme and approach (Singh and Narayanan, 1993).

In the study of trait inter-relationships, correlation and path analyses have been conducted in several crops; correlations indicating the nature and degree of interrelationship among yield and its component characters; whereas path analysis indicates direct and indirect contributions of the characters towards yield (Akanda and Mundt, 1996). In path coefficient analysis, grain yield is considered a dependent variable and the remaining traits are considered as independent (causal) variables (Singh and Chaundhary, 1977). A path coefficient is simply a standardised partial regression coefficient; as such estimates the direct influence of one variable upon another and permits separation of correlation coefficients into components of direct and indirect effects (Dewey and Lu, 1959). The direct contribution of an independent variable to the variation observed in the dependent variable can be determined with reduced confounding influences caused by multicolinearity. The purposes of conducting path analysis in this study were to determine both effects of blast disease on yield components of finger millet and the relative importance of the disease and yield components on yield and to unravel the opposing effects between variables along the different paths of influence.

The objective of this study was to determine the variability and trait interrelationships in Ugandan finger millet germplasm for selected agronomic traits and blast disease reaction, and asses the genetic potential of these materials for use in the breeding programme.

\section{Materials and methods}

A total of four experiments were conducted at National Semi-Arid Resources Research Institute NaSARRI (Latitude $1^{\circ} 29^{\prime} 39 \mathrm{~N}$ Longitude $33^{\circ} 27^{\prime}$ $19 \mathrm{E} 1085$ m.a.s.1, ) and Ikulwe $\left(0^{\circ} 27^{\prime} 3 \mathrm{~N}\right.$; $33^{\circ} 28^{\prime} 16 \mathrm{E} ; 1157$ m.a.s.1,) satellite station in eastern Uganda in 2011 and 2012 main cropping seasons using 100 cultivars and landraces collected from the different finger millet growing agro-ecologies of the country. Some introductions from the International Crops Research Institute for Semi and Arid Tropics (ICRISAT), Nairobi, were also sown along side five improved cultivars from NaSARRI. A lattice design, with three replications, and plot size of six rows of $3 \mathrm{~m}$ long and $1.5 \mathrm{~m}$ wide, with row spacing of $30 \mathrm{~cm}$ and plant to plant spacing of $10 \mathrm{~cm}$ was used. Data were collected on leaf blast incidence, leaf blast severity, head blast incidence and head blast severity under natural infestation. Other parameters included days to $50 \%$ flowering, number of productive tillers, flag leaf length, flag leaf width, fingers per head, grain mass per head, threshing percentage and grain yield $\mathrm{ha}^{-1}$. Additional data were taken on finger length, and width, peduncle length, panicle length and width and plant height. Data was taken from 40 randomly selected plants from two mid rows for each of the accessions following finger millet descriptors (IBPGR, 1985). Some of the descriptors assessed included:

i. Plant height $(\mathrm{cm})$ from ground level to the tip of inflorescence (head) at dough stage;

ii. Productive tillers: number of basal tillers which bear mature heads; 
iii. Days to $50 \%$ flowering from sowing to stage when heads emerge from 50\% of main tillers;

iv. Finger length $(\mathrm{cm})$ from base to the tip of longest spike (finger) on main tiller at dough stage

v. Finger number on main head at dough stage; and

vi. Grain yield per plant: mean was taken from ten plants, post-harvest.

a. Grain yield (tonnes ha' ${ }^{-1}$ ): measured as grain mass was taken from the fourty plants, post-harvest and converted to tons $\mathrm{ha}^{-1}$. Using the formula:

b. Grain yield $\left(\mathrm{t} \mathrm{ha}^{-1}\right)=$

\section{$\underline{333,333 \times \text { yield of the } 40 \text { plants }(\mathrm{kg})}$ $40 \times 1000$}

Leaf blast (LB) incidence and severity were recorded at booting stage approximately 45 to 50 days after emergence as recommended by Babu et al. (2013) and head blast (HB) observations were recorded at the time of grain maturity. The disease incidence was calculated as the number of diseased plants divided by the total number of plants sampled per plot. Leaf blast severity was estimated on the basis of leaf area covered by lesions using $1-5$ rating scale of Mackill and Bonman (1992). The percent disease index (PDI) for determining leaf blast severity (LBS) was calculated using the formula given by Wheeler (1969) as follows:

$\mathrm{LBS}=\underline{\mathrm{n}}_{1} \times 1+\mathrm{n}_{2} \times 2+\mathrm{n}_{3} \times 3 \mathrm{n}_{4} \times 4+\mathrm{n}_{5} \underline{\times 5}$

Total number of leaves observed $\mathrm{x}$ maximum grade

Where: $\mathrm{n}_{1}$ to $\mathrm{n}_{5}$ represent the total number of leaves falling under $1-5$ scale, respectively.

The resultant percentages were categorised as follows: immune $-0.0 \%$, highly resistant $0.1-5 \%$, resistant $5.1-$ $10 \%$, moderately susceptible $10.1-25 \%$ and susceptible $>25 \%$.

For head blast severity, all heads from the 10 plants were used to determine blast severity at maturity. For each head, proportions of spikelets affected by the disease were estimated and a Standard Evaluation System (SES, IRRI, 1996) was adopted. This is based on the number of heads, and head blast severity computed as follows:

$\mathrm{HBS}=(10 \times \mathrm{xN} 1)+(20 \times \mathrm{N} 2)+(40 \times \mathrm{N} 5)+(70 \times \mathrm{NN} 7)+(100 \times \mathrm{NN} 9)$

Total number of panicles

Where:

N1 - N9 are number of panicles infected with the disease, multiplied with the corresponding portion infected. From the resultant percentages, the genotypes were categorised as follows: $0 \%$; no incidence or immune, less than $5 \%$ as highly resistant, $5-10 \%$ resistant, $11-25 \%$ moderately resistant, $26-50 \%$ susceptible and more than $50 \%$ highly susceptible.

\section{Data analysis}

All data collected were subjected to analysis of variance (ANOVA) to obtain mean squares for genotypes, and the residual using GenStat (edition 12) (Payne et al., 2009). The genotypic $\left(\sigma^{2}{ }_{\mathrm{g}}\right)$, phenotypic $\left(\sigma_{\mathrm{p}}^{2}\right)$, interaction $\left(\sigma_{\mathrm{ge}}^{2}\right)$ and error $\left(\sigma_{\mathrm{e}}^{2}\right)$ variances were computed using the formulae of Burton and De Vane (1953) (cited in Bezaweletaw et al., 2006) 
as $\sigma_{\mathrm{g}}^{2}=(\mathrm{MSg}-\mathrm{MSge}) / \mathrm{re} ; \sigma_{\mathrm{p}}^{2}=\sigma_{\mathrm{g}}^{2}+$ $\left.\sigma^{2} \mathrm{ge}\right) / \mathrm{e}+\sigma^{2} \mathrm{e} / \mathrm{re}$

Where:

MSg = genotypic mean square, MSge = mean square due to genotype $x$ environmental interaction, $\mathrm{e}=$ number of environments and $r=$ the number of replications. $\sigma^{2}$ ge $=(\mathrm{MSge}-\mathrm{Mse}) / \mathrm{r}$, Where $\mathrm{MSe}=$ combined error mean square.

The phenotypic (PCV), genotypic (GCV), environmental (ECV), and genotype $x$ environment (GECV) coefficients of variability were estimated following the procedures of Kumar et al. (1985);

$\mathrm{PCV}=100\left(\sigma_{\mathrm{p}}\right) / \overline{\mathrm{x}} ; \mathrm{GCV}=100\left(\sigma_{\mathrm{g}}\right) / \overline{\mathrm{x}} ;$

$\mathrm{ECV}=100\left(\sigma_{\mathrm{e}}\right) / \overline{\mathrm{x}}$; and $\mathrm{GECV}=100\left(\sigma_{\mathrm{ge}}\right) /$ $\overline{\mathrm{x}}$

Where: $\sigma_{\mathrm{p}}=$ phenotypic standard deviation, $\sigma_{\mathrm{g}}=$ genetic standard deviation, $\sigma_{\mathrm{e}}=$ environmental standard deviation, $\sigma_{\mathrm{ge}}$ $=$ genotypic $\mathrm{x}$ environmental standard deviation and $\overline{\mathrm{x}}=$ trait mean.

Heritability $\left(\mathrm{H}^{2}\right)$ in the broad-sense was estimated by the formulae of Allard (1960);

$H^{2}=\sigma_{g}^{2} / \sigma_{p}^{2}$

Expected genetic advance (GA), assuming selection intensity of $5 \%$ was estimated according to the method of Johnson et al. (1955);

$\mathrm{GA}=\mathrm{K} \mathrm{H}^{2} \sigma_{\mathrm{p}}$

Where $\mathrm{K}$ was the selection intensity constant at $5 \%(\mathrm{~K}=2.056), \mathrm{H}^{2}$ the broad sense heritability and $\sigma_{p}$ the phenotypic standard deviation.

The genetic advance as a percent of mean was obtained as:

GA $(\%$ of mean $)=100(\mathrm{GA} / \overline{\mathrm{x}})$

Where: $\mathrm{GA}=$ genetic advance, and $\overline{\mathrm{x}}=$ population mean for the trait considered.

The heritability estimates were classified according to Robinson et al. (1949) into three classes, that is $0-30 \%$ low, $31-60 \%$ as medium, and $>60 \%$ as high. On the other hand, Johnson et al. (1955) categorised genetic advance as a percentage of mean into $0-10 \%$ low, 10 $-20 \%$ moderate and $>20 \%$ as high. These categorisations were used in this study.

\section{Correlation and path analysis}

The correlation coefficients between all possible pairs of quantitative traits and path analysis were conducted and tested for their significance in SAS Programme Version 9.2 (SAS, Cramer et al., 1997) using PATHSAS software. The path coefficient analysis was used to decompose the correlation coefficients into direct and indirect effects, to clarify the relationships between different traits with grain yield.

The direct and indirect effects of yield related to quantitative traits on grain yield, were calculated following the formula suggested by Dewey and Lu (1959) (cited in Lule et al., 2012) as:

$r_{i j}=P_{i j}+r_{i k} P_{k j}$

Where:

$r_{i j}$ is mutual association between the independent character (i) and dependent 
character ( $\mathrm{j}$ ) as measured by the correlation coefficient; $\mathrm{P}_{\mathrm{ij}}$ is the component of direct effects of the independent character (i) and dependent character (j) as measured by the path coefficient and; $\Sigma r_{i k} P_{k j}$ is the summation of indirect effect of a given dependent character (j) via all other independent characters (k). Residual effects, which determine how best the causal factor accounts for the variability of the dependent character, was estimated by:

$$
1-\mathrm{R}^{2}
$$

Where: $R^{2}=P_{i j} r_{i j}, P_{i j}=$ component of direct effects of the independent character (i) and dependent character (j) as measured by the path coefficient; $r_{i j}=$ mutual association between the independent character (i) and dependent character ( $\mathrm{j}$ ) as measured by the correlation coefficient.

Scales suggested by Lenka and Mishra (1973) in rice studies, and used by Lule $e t$ al. (2012) of path coefficients values 0.00 to 0.09 as negligible, 0.10 to 0.19 as low, 0.20 to 0.29 moderate and 0.30 to 0.99 as high path coefficient were used in this study. This scale was supplemented by the significance test of the direct effects using PATHSAS software in SAS computer package.

\section{Results}

\section{Variation among the accessions}

The analysis of variance results (Table 1) showed highly significant $(\mathrm{p}<0.001)$ differences between the genotypes for all the traits studied, indicating that the accessions were highly variable. The coefficient of variations ranged from $5.3 \%$ for days to $50 \%$ flowering to $28.1 \%$ for leaf blast severity.

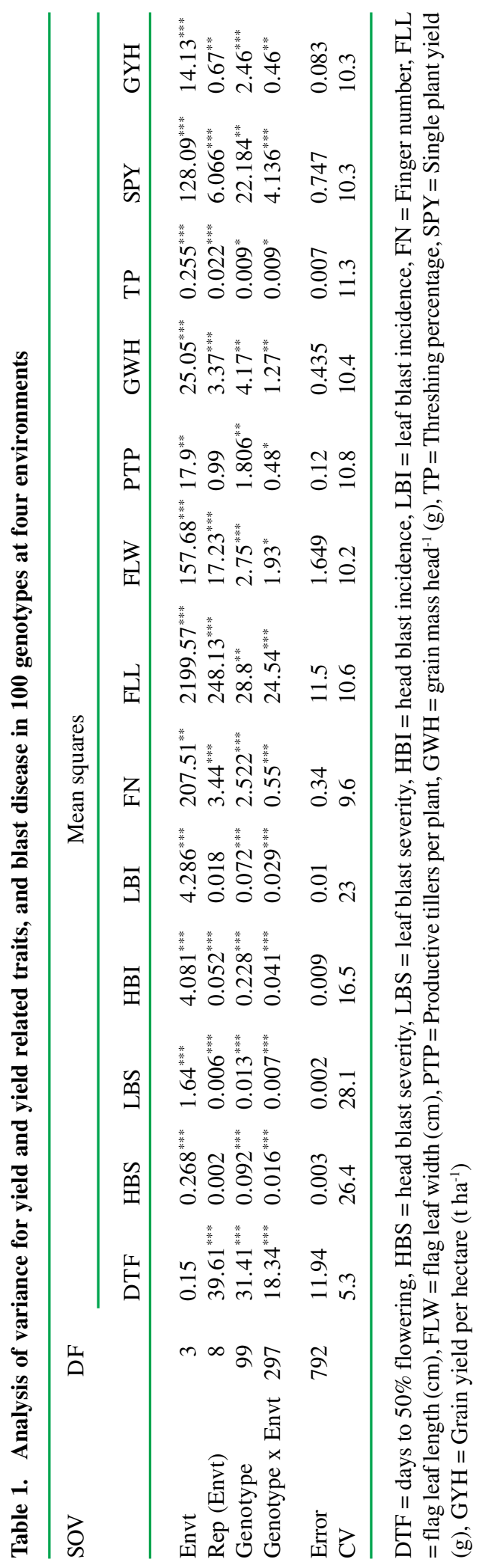


Estimates of variability, heritability and genetic advance among the accessions Table 2 shows the highest genotypic and phenotypic variances were exhibited by days to $50 \%$ flowering, single plant yield, grain mass head ${ }^{-1}$, number of tillers plant $^{-1}$, flag leaf length and finger number; whereas the lowest were observed in threshing percentage and leaf blast severity. Traits such as head blast severity and incidence, productive tillers plant ${ }^{-1}$, grain mass head ${ }^{-1}$ and grain yield $\mathrm{ha}^{-1}$ had $\mathrm{H}^{2}$ values above $60 \%$, hence exhibiting high heritability (Robinson et al., 1949). These traits depict a large proportion of the phenotypic variance was accounted for by the genetic component. The phenotypic (PCV) and genotypic (GCV) coefficient of variations of the different traits computed based on analysis of variance, ranged from 3.17 to 57.0 for days to $50 \%$ flowering and head blast severity, and 0.89 to 39.2 for threshing percentage and head blast severity, respectively. High GA, as a percentage of means according to classification of Johnson et al. (1955), were obtained for head blast severity, leaf blast severity, head blast incidence, leaf blast incidence, number of productive tillers plant ${ }^{-1}$ and grain yield. The lowest values were obtained with days to $50 \%$ flowering, threshing percentage, flag leaf width and flag leaf length.

\section{Pearson's correlation coefficients}

The correlations among the traits are presented in Table 3. There was a high and positive correlation between grain yield ha ${ }^{-1}$ and panicle width, finger number, plant height, number of productive tillers, grain mass head ${ }^{-1}$, threshing percentage and single plant yield. However, the correlations were negative with leaf blast incidence, head blast incidence, head blast severity and days to $50 \%$ flowering.
Meanwhile, head blast severity had significant positive correlation with leaf blast incidence and head blast incidence, but negatively with panicle width, flag leaf length, days to $50 \%$ flowering, grain mass per head and single plant yield. Plant height, on the other hand, had positive significant correlations with panicle length, finger length, peduncle length, flag leaf length, days to $50 \%$ flowering.

\section{Path coefficient analysis}

The correlation coefficients were further divided into direct and indirect effects using path coefficient analysis (Table 4). Of the 11 independent variables, six had positive direct effect values, namely finger length (0.014), finger width (0.044), finger number $(0.001)$, number of productive tillers (0.527), grain mass per head (0.625) and threshing percentage $(0.056)$. On the other hand, leaf blast severity $(-0.062)$, head blast incidence (-0.09), head blast severity $(-0.103)$, days to $50 \%$ flowering $(-0.012)$ and plant height $(-0.043)$ showed negative direct effects.

Grain mass head ${ }^{-1}$ exerted the highest positive direct effect on grain yield (0.625) and it also exhibited a negative low indirect effect (-0.114) via number of productive tillers. Productive tillers exerted the second highest positive direct effect $(0.527)$ on grain yield ha ${ }^{-1}$. It also exhibited low negative indirect effect (-0.136) via grain mass head ${ }^{-1}$. All the remaining independent variables exhibited negligible direct effects on grain yield ha ${ }^{-1}$ with the exception of head blast severity, which showed a low negative direct effect ($0.103)$ with a high indirect effect $(0.298)$ via grain mass head ${ }^{-1}$. Of the variables with negligible indirect effects, however, finger length exhibited a low negative indirect effect (-0.137) via number of productive tillers. Days to $50 \%$ flowering 


\begin{tabular}{|c|c|c|c|c|c|c|c|c|c|c|c|c|}
\hline Trait & Mean & GV & PV & GEV & EV & GCV & PCV & GECV & $\mathrm{ECV}$ & $\mathrm{H}^{2}$ & GA & $\begin{array}{l}\text { GA as } \\
\% \text { of mean }\end{array}$ \\
\hline Days to $50 \%$ flowering & 64.74 & 1.089 & 4.214 & 2.130 & 0.995 & 1.62 & 3.17 & 2.25 & 1.54 & 51.10 & 4.430 & 6.84 \\
\hline Head blast severity & 0.20 & 0.006 & 0.014 & 0.004 & 0.003 & 39.20 & 57.00 & 32.00 & 26.00 & 68.40 & 0.163 & 79.90 \\
\hline Leaf blast severity & 0.15 & 0.001 & 0.004 & 0.002 & 0.002 & 16.20 & 42.00 & 27.00 & 28.00 & 38.10 & 0.050 & 33.30 \\
\hline Leaf blast incidence & 0.43 & 0.004 & 0.020 & 0.006 & 0.010 & 14.00 & 33.00 & 19.00 & 23.00 & 42.40 & 0.120 & 27.90 \\
\hline Head blast incidence & 0.57 & 0.017 & 0.037 & 0.011 & 0.009 & 22.90 & 33.80 & 18.40 & 16.60 & 67.80 & 0.270 & 47.40 \\
\hline Finger number & 6.85 & 0.164 & 0.574 & 0.070 & 0.340 & 5.91 & 11.06 & 3.86 & 8.51 & 53.40 & 0.830 & 12.14 \\
\hline Fag leaf length $(\mathrm{cm})$ & 40.58 & 0.355 & 16.310 & 4.350 & 11.600 & 1.47 & 9.95 & 5.14 & 8.39 & 14.80 & 1.230 & 3.03 \\
\hline Flag leaf width (mm) & 12.65 & 0.067 & 1.905 & 0.028 & 1.810 & 2.05 & 10.91 & 1.32 & 10.64 & 18.80 & 0.533 & 4.20 \\
\hline Productive tillers plant $^{-1}$ & 2.34 & 0.111 & 0.284 & 0.053 & 0.120 & 14.21 & 22.77 & 9.84 & 14.89 & 62.41 & 0.684 & 29.20 \\
\hline Threshing percentage & 0.71 & 0.001 & 0.007 & 0.001 & 0.007 & 0.89 & 12.04 & 3.73 & 11.44 & 7.39 & 0.014 & 2.00 \\
\hline Grain mass head ${ }^{-1}$ & 4.21 & 0.408 & 1.121 & 0.278 & 0.435 & 15.17 & 25.15 & 12.52 & 15.67 & 60.4 & 1.320 & 31.23 \\
\hline Grain yield ha-1 (tonnes) & 2.81 & 0.167 & 0.379 & 0.123 & 0.089 & 14.54 & 21.91 & 12.48 & 10.62 & 66.4 & 0.840 & 29.90 \\
\hline Single plant yield (grammes) & 8.43 & 1.504 & 3.416 & 1.112 & 0.800 & 14.55 & 21.92 & 12.51 & 10.61 & 66.4 & 2.520 & 29.90 \\
\hline
\end{tabular}

$\mathrm{GV}=$ genetic variance, $\mathrm{PV}=$ phenotypic variance, $\mathrm{GEV}=$ genotype $\mathrm{x}$ environment variance, $\mathrm{EV}=$ environmental variance, $\mathrm{GCV}=$ genotypic coefficient of variation, $\mathrm{PCV}=$ phenotypic coefficient of variation, $\mathrm{GECV}=$ genotype $\mathrm{x}$ environment coefficient of variability, ECV = environmental coefficient of variation, $\mathrm{H}^{2}$ = broad-sense heritability, $\mathrm{GA}=$ genetic advance 
Table 3. Pearson's correlation coefficients in selected finger millet traits

\begin{tabular}{|c|c|c|c|c|c|c|c|c|c|c|c|c|c|c|c|c|c|c|c|}
\hline & LBI & LBS & HBI & HBS & PANL & PANW & LFL & LFW & PEDL & FLL & FLW & DTF & FN & PHT & PTP & GWH & TP & SPY & $\mathrm{GYH}^{1}$ \\
\hline LBI & 1.00 & & & & & & & & & & & & & & & & & & \\
\hline LBS & $0.444 * *$ & 1.00 & & & & & & & & & & & & & & & & & \\
\hline HBI & 0.071 & -0.012 & 1.00 & & & & & & & & & & & & & & & & \\
\hline HBS & $0.271 * *$ & 0.046 & $0.518 * *$ & 1.00 & & & & & & & & & & & & & & & \\
\hline PANL & 0.100 & -0.154 & $0.409 * *$ & 0.177 & 1.00 & & & & & & & & & & & & & & \\
\hline PANW & -0.073 & 0.013 & -0.133 & $-0.293 * *$ & -0.110 & 1.00 & & & & & & & & & & & & & \\
\hline LFL & 0.062 & $-0.205^{*}$ & $0.332 * *$ & 0.119 & $0.969 * *$ & -0.096 & 1.00 & & & & & & & & & & & & \\
\hline LFW & 0.072 & 0.017 & 0.151 & -0.015 & 0.160 & $0.354 * *$ & 0.144 & 1.00 & & & & & & & & & & & \\
\hline PEDL & 0.050 & -0.013 & 0.033 & 0.033 & 0.101 & -0.009 & 0.137 & -0.039 & 1.00 & & & & & & & & & & \\
\hline FLL & -0.168 & -0.164 & $-0.238^{*}$ & $-0.342 * *$ & 0.162 & -0.006 & $0.218^{*}$ & 0.136 & $-0.240^{*}$ & 1.00 & & & & & & & & & \\
\hline FLW & 0.057 & -0.025 & 0.002 & -0.121 & $0.253^{*}$ & 0.112 & $0.271 * *$ & $0.286 * *$ & 0.044 & $0.396 * *$ & 1.00 & & & & & & & & \\
\hline DTF & $-0.279 * *$ & -0.119 & $-0.442 * *$ & $-0.427 * *$ & -0.111 & 0.047 & -0.017 & -0.079 & -0.087 & $0.630 * *$ & 0.064 & 1.00 & & & & & & & \\
\hline FN & -0.144 & -0.156 & -0.033 & -0.195 & 0.031 & $0.253^{*}$ & 0.059 & 0.050 & $0.267 * *$ & 0.184 & $0.387 * *$ & 0.109 & 1.00 & & & & & & \\
\hline PHT & $-0.270^{* *}$ & $-0.365^{* *}$ & -0.098 & $-0.204 *$ & $0.253^{*}$ & 0.059 & $0.303 * *$ & 0.024 & $0.267 * *$ & $0.292 * *$ & -0.006 & $0.356^{* *}$ & $0.286^{* *}$ & 1.00 & & & & & \\
\hline PTP & -0.183 & 0.002 & -0.022 & -0.029 & $-0.243 *$ & 0.117 & -0.260 ** & -0.036 & $0.274 * *$ & $-0.235^{*}$ & $-0.364 * *$ & 0.004 & -0.063 & -0.006 & 1.00 & & & & \\
\hline GWT & $-0.205^{*}$ & -0.135 & $-0.287 * *$ & $-0.476^{* *}$ & 0.035 & 0.173 & 0.127 & 0.071 & -0.079 & $0.448 * *$ & $0.393^{* *}$ & $0.483 * *$ & $0.423 * *$ & $0.315^{* *}$ & $-0.217^{*}$ & 1.00 & & & \\
\hline TP & -0.107 & -0.174 & 0.005 & $-0.219 *$ & 0.03 & 0.100 & 0.060 & -0.076 & 0.111 & -0.006 & 0.039 & 0.018 & 0.180 & 0.162 & 0.026 & $0.411^{* *}$ & 1.00 & & \\
\hline SPY & $-0.334 * *$ & -0.144 & $-0.314 * *$ & $-0.463^{* *}$ & -0.147 & $0.354 * *$ & -0.77 & 0.053 & 0.066 & 0.153 & 0.079 & $-0.366^{* * *}$ & $0.265^{* *}$ & $0.212^{*}$ & $0.393 * *$ & $0.603 * *$ & $0.350 * *$ & 1.00 & \\
\hline $\mathrm{GYH}^{1}$ & $-0.334 * *$ & -0.144 & $-0.313^{*}$ & $-0.463 * *$ & -0.146 & $0.354 * *$ & -0.076 & 0.053 & 0.067 & 0.153 & 0.079 & $0.366^{* *}$ & $0.265^{* *}$ & $0.214 *$ & $0.393^{* *}$ & $0.603^{* *}$ & $0.350^{* *}$ & $1.00^{* *}$ & 1.00 \\
\hline
\end{tabular}




\begin{tabular}{|c|c|c|c|c|c|c|c|c|c|c|c|c|c|}
\hline & $\begin{array}{l}\text { Direct } \\
\text { effect }\end{array}$ & $\begin{array}{c}\text { Leaf } \\
\text { blast } \\
\text { severity }\end{array}$ & $\begin{array}{l}\text { Head } \\
\text { blast } \\
\text { incidence }\end{array}$ & $\begin{array}{l}\text { Head } \\
\text { blast } \\
\text { severity }\end{array}$ & $\begin{array}{l}\text { Finger } \\
\text { length }\end{array}$ & $\begin{array}{l}\text { Finger } \\
\text { width }\end{array}$ & $\begin{array}{l}\text { Days to } \\
50 \% \\
\text { flowering }\end{array}$ & $\begin{array}{l}\text { Finger } \\
\text { number }\end{array}$ & $\begin{array}{l}\text { Plant } \\
\text { height }\end{array}$ & $\begin{array}{l}\text { Productive } \\
\text { tillers }\end{array}$ & $\begin{array}{c}\text { Grain } \\
\text { mass/ } \\
\text { head }\end{array}$ & $\begin{array}{c}\text { Threshing } \\
(\%)\end{array}$ & \\
\hline Leaf blast severity & $-0.062^{\text {ns }}$ & - & 0.0011 & -0.0047 & -0.0029 & 0.0008 & 0.0014 & -0.0002 & 0.0157 & 0.0011 & -0.0844 & -0.0097 & -0.144 \\
\hline Head blast incidence & $-0.090^{\text {ns }}$ & 0.0007 & - & -0.0534 & 0.0047 & 0.0066 & 0.0053 & -0.0004 & 0.0042 & -0.0116 & -0.1794 & 0.0003 & -0.313 \\
\hline Head blast severity & $-0.103^{n s}$ & -0.0029 & -0.0466 & - & -0.0017 & -0.0007 & 0.0051 & -0.0002 & 0.0088 & -0.0153 & -0.2975 & -0.0123 & -0.463 \\
\hline Finger length & $0.014^{\text {ns }}$ & 0.0127 & -0.0299 & -0.0123 & - & 0.0063 & 0.0002 & 0.0001 & -0.013 & -0.1370 & 0.0794 & 0.0034 & -0.076 \\
\hline Finger width & $0.044^{\mathrm{ns}}$ & -0.0011 & -0.0136 & 0.0016 & 0.002 & - & 0.001 & 0.0001 & -0.001 & -0.019 & 0.0444 & -0.0043 & 0.053 \\
\hline Days to $50 \%$ flowering & $-0.012^{n s}$ & 0.0074 & 0.0398 & 0.044 & -0.0002 & -0.0035 & - & 0.0001 & -0.0153 & 0.0021 & 0.3019 & 0.0010 & 0.366 \\
\hline Finger number & $0.001^{\text {ns }}$ & 0.0097 & 0.003 & 0.0201 & 0.0008 & 0.0022 & -0.0013 & - & -0.0123 & -0.0332 & 0.2644 & 0.0101 & 0.265 \\
\hline Plant height & $-0.043^{n s}$ & 0.0226 & 0.0088 & 0.021 & 0.0042 & 0.0011 & -0.0043 & 0.0003 & - & -0.0032 & 0.1969 & 0.0091 & 0.214 \\
\hline Productive tillers & $0.527^{* * * *}$ & -0.0001 & 0.002 & 0.003 & -0.0036 & -0.0016 & -0.0001 & -0.0001 & 0.0003 & - & -0.1356 & 0.0015 & 0.393 \\
\hline Grain mass head ${ }^{-1}$ & $0.625^{* * * *}$ & 0.0084 & 0.0258 & 0.049 & 0.0018 & 0.0031 & -0.0058 & 0.0004 & -0.0136 & -0.1144 & - & 0.023 & 0.603 \\
\hline Threshing \% & $0.056^{\mathrm{ns}}$ & 0.0108 & -0.0005 & 0.0226 & 0.0008 & -0.0033 & -0.0002 & 0.0002 & -0.007 & 0.0137 & 0.2569 & - & 0.350 \\
\hline
\end{tabular}

Residual effects $(\mathrm{h})=0.417 ; \mathrm{R}^{2}$ Value $=0.71{ }^{*}{ }^{* * * * * *, n s ;}$ are significant at P levels $0.05,0.01,0.001$ and non-significant respectively 
showed a high positive indirect effect (0.302) via grain mass head ${ }^{-1}$; finger number and threshing percentage showed moderate positive indirect effects $(0.264$, 0.257 , respectively) via grain mass head ${ }^{1}$, while plant height exhibited low positive indirect effect $(0.197)$ via grain mass per head.

\section{Discussion}

Variability, heritability and genetic gain A wide range of variation was observed in all the traits studied indicating existence of broad variability, which would provide a genuine opportunity for genetic improvement through selection and hybridisation. Similar findings were reported in finger millet by Lule et al. (2012) and Bezaweletaw et al. (2006) on Ethiopian germplasm. Since there were significant differences, mostly contributed by genotypes as compared to environment, it is an indication that the collection had high variability in terms of these traits which can be exploited for improvement; since a large portion of the phenotypic variance was directly contributed by the genetic component and unaltered by the environment in agreement with Falconer and Mackay (1996).

It has also been suggested that heritability estimates, genetic advance as a percentage of mean and their combination could be useful in predicting the performance of the best selected individuals in a population (Johnson et al., 1955). Based on the current study, traits exhibiting high broad-sense heritability estimates depicted a large proportion of the phenotypic variance accounted for by the genetic component. This indicates the existence of reasonable inherent variability that remained unaltered by environmental conditions among the genotypes, which in turn can be more useful for exploitation in hybridisation and/or selection. Overall, the phenotypic coefficients of variation (PCV) estimates were higher than the genotypic coefficients of variation (GCV) as expected (Falconer and Mackay, 1996) which shows that the apparent variation was not only due to genotypes, but also to the influence of the environment. In the majority of the traits, however, the environmental coefficients of variation (ECV) estimates were lower than both genotypic and phenotypic coefficient of variation, which implies that the environmental role was less for expression of such traits. In these cases, the traits may be employed to select for superior genotypes among the progeny that may be generated from their crosses, since the traits would be transmitted to the progenies.

High heritability estimates and high genetic advance, as a percentage of mean observed in certain traits was probably indicative of additive gene action. These traits could be improved through selection, whereas moderate heritability and low genetic advance might imply non-additive gene effects. Improvement in such traits could be achieved by crossing the landraces to genotypes with higher values for such traits; followed by selecting progenies segregating positively for such traits. On the other hand, low heritability traits and low genetic advance could probably suggest gene interactions, making selecting in the early generation of progenies ineffective.

\section{Correlations analysis}

High positive associations between grain yield ha ${ }^{-1}$ and panicle width (0.354), finger number $(0.265)$, number of productive tillers $(0.393)$, grain mass head ${ }^{-1}(0.603)$, single plant yield (1.00) and threshing percentage $(0.350)$ shows that yield is a 
result of both growth and yield components and, therefore, a complex trait. Grain yield, however, was highly negatively associated with leaf blast incidence $(r=0.334)$, head blast incidence $(r=0.313)$, head blast severity $(r=0.463)$ and days to $50 \%$ flowering $(\mathrm{r}=0.366)$. The negative association with blast disease indicates that both leaf blast and head blast reduced yield, but head blast was probably more important in yield reduction compared to leaf blast since both incidence and severity were significantly associated with grain yield. This is probably because head blast can be particularly more destructive (Takan et al., 2004) as it directly reduces final yield through reduction in grain number and grain mass. Babu et al. (2013) also suggested a buildup of adult plant resistance to leaf blast, which seemed to reduce the impact of leaf blast as the current study seemed to suggest.

These results further revealed that besides selection for grain yield per se, indirect selection for panicle width, finger number, number of productive tillers, grain mass per head, threshing percentage and plant height (in case of non-lodging materials or conditions) can lead to improvement in grain yield, since they exhibited significantly positive correlation with grain yield. However, there should be a balance among characters in selection, particularly between number of productive tillers and grain mass head ${ }^{-1}$ which had a significant negative correlation between themselves; and plant height which could lead to lodging (Oduori, 2008).

Leaf blast incidence was highly and positively correlated with leaf blast severity (0.444) and head blast severity (0.271) (Table 3). These results revealed that highly susceptible cultivars to leaf blast were also susceptible to head blast, similar to results of Quynh and Bong (1999), who discovered that varieties with high and moderate resistance to leaf blast normally maintained the resistance to panicle blast in rice; yet most varieties with unstable resistance to leaf blast were found to be susceptible to panicle blast. The findings seem to suggest an interaction between leaf blast incidence with both leaf blast severity and head blast severity; indicating that accessions with high incidences of leaf blast also show high leaf and head blast severity. Lenne et al. (2007) and Takan et al. (2004) clearly proved that isolates causing leaf and panicle blast on millet were genetically similar, indicating that the same strains were capable of causing different expressions of blast under suitable agro-ecological conditions. Similarly, there was a very high positive association between head blast incidence and severity, an indication that accessions with high incidence also tended to have high severity.

\section{Path coefficient analysis}

This study has revealed high positive and significant direct effects of grain mass head $^{-1}$ and number of productive tillers; and their positive association to grain yield $\mathrm{ha}^{-1}$ is an indication that these were the most important traits (contributors) alongside head blast severity, which showed a negative direct effect. Among the selected variables, it is evident that these are the variables with high value to selection. However, caution is required since, for instance, number of productive tillers exhibited low negative indirect effect via grain mass head ${ }^{-1}$ and likewise grain mass head ${ }^{-1}$ also exhibited a low negative indirect effect via number of productive tillers. Head blast severity, which showed a low negative direct effect 
with a high indirect effect via grain mass head $^{-1}$ revealed that efforts must be made to ensure only heads free from, or with very low levels of head blast disease are selected as it is a more important biotic factor compared to leaf blast. This is probably because the disease occurs at the time of determination of yield components directly and indirectly through grain mass head ${ }^{-1}$ (Torres and Teng, 1993). Further, Takan et al. (2004) observed that seed borne inoculum contributed to initial blast development in the field, where high disease incidence was observed in plantings with seeds containing a high proportion of inoculum.

The role of head blast in influencing yield is well documented by Oduori (2008) and Takan et al. (2004). It is mainly attributed to reduction in the number of seeds head ${ }^{-1}$ or grain mass, therefore, the number and mass are expected to be greater in the absence than in presence of the disease, as a result increased number of seeds head ${ }^{-1}$ and/or mass would result in increased total yield. The negative effect of the disease on yield was also reported by Akanda and Mundt (1996) who found that path analysis showed all yield components to be negatively affected by rust on wheat. Plots with higher tiller densities were expected to generate higher yield, but might also provide a more favourable microclimate or microenvironment for blast disease. This effect was found in the rice pathosystem, where leaf blast was positively correlated with number of effective tillers by Torres and Teng (1993).

Considering variables with negligible direct effects $(<0.09)$, however, finger length exhibited a low negative indirect effect via number of productive tillers (0.137); days to $50 \%$ flowering showed a high positive indirect effect through grain mass per head (0.302). In contrast with the findings of Oduori (2008), but consistent with findings of Lule et al. (2012) and Bezaweletaw (2006), threshing percentage of finger millet showed moderate positive indirect effects through grain mass head ${ }^{-1}(0.264$ and 0.257 , respectively); while plant height exhibited low positive indirect effect through grain mass per head. This showed these traits could be used for indirect selection. From this study, it is also possible to simultaneously select early maturing, tall cultivars with high finger numbers for high yields due to their high indirect effects through head grain mass. Therefore, it can be inferred that genetic and environmental factors that delay flowering of the crop and increase height and the other characters may also require attention in improvement programmes as these indirectly contribute to yield via grain yield per head.

\section{Conclusion}

The study has provided crucial information on variability in finger millet accessions in terms of selected traits and reaction to leaf and head blast disease. It revealed that both genetic and phenotypic variability exist within the Uganda germplasm in all traits that were studied. Also that head blast severity, head blast incidence, grain mass head ${ }^{-1}$, grain yield $\mathrm{ha}^{-1}$, and productive tillers plant $^{-1}$ possess high heritability values depicting large proportion of phenotypic variance was accounted for by the genetic component in these traits. Additionally, high genetic advance as a percentage of means are evident for head blast severity, leaf blast severity, head blast incidence, leaf blast incidence, number of productive tillers plant $^{-1}$ and grain yield. Traits with both 
high heritability and genetic advance as a percentage of mean would be transmitted to their progeny from crosses involving the 100 genotypes used in this study. These included blast disease resistance and grain yield. Lastly, productive tillers plant ${ }^{-1}$ and grain mass per head have positive significant correlation to yield and high positive direct effects; therefore, selecting for these traits would probably result in high yielding genotypes.

\section{Acknowledgement}

This research was supported by the Alliance for a Green revolution in Africa (AGRA) through the African Centre for Crop Improvement (ACCI) and the National Agricultural Research Organisation (NARO). We are grateful for the efforts of the field staff at both NaSARRI and Ikulwe for their support which enabled successful completion of this work. Special thanks and appreciation to administrative staff at ACCI and NaSARRI for timely logistical support.

\section{References}

Akanda, S.I. and Mundt, C.C. 1996. Path coefficient analysis of the effects of stripe rust and cultivar mixtures on yield and yield components of winter wheat. Theoretical and Applied Genetics 92:666-672.

Allard, R.W. 1960. Principles of Plant Breeding. John Wiley and Sons Inc., New York, USA.

Babu, T.K., Thukar, R.P., Upadhyaya, H.D., Reddy, P.N., Sharma, R.,Girish, A.G. and Sarma, N.D.R.K. 2013. Resistance to blast (Magnaporthe grisea) in a mini-core collection of finger millet germplasm. European Journal of Plant Pathology. Open
Access Repository, International Crops Research Institute for Semi-Arid Tropics. Available online http:// dx.doi.org/10.1007/s10658-012-00862/ (date accessed: 10/04/2013).

Bezaweletaw, K., Sripichitt, P., Wongai, W. and Hongtrakul,V. 2007. Phenotypic diversity of Ethiopian finger millet [Eleusine coracana (L.) Gaertn]. In: Relation to geographic regions as an aid to germplasm collection and conservation. Kasetsart Journal of Natural Science 41:7-14.

Bezaweletaw, K., Sripichitt, P.,Wongai, W. and Hongtrakul,V. 2006. Genetic variation, heritability and path-analysis in Ethiopian finger millet [Eleusine coracana (L.) Gaertn] Landraces. Kasetsart Journal of Natural Science 40:322-334.

Cramer, C.S., Wehne, T.C. and Donaghy, S.B. 1997. PATHSAS 1.0. Programme for analysis of path coefficients using SAS. SAS Institute Inc., Cary, NC, USA.

Dewey, D.R. and Lu, K.H. 1959. A correlation and path coefficient analysis of crested wheat grass grain production. Agronomy Journal 51:515-518.

Falconer, D.S. and Mackay,T.F.C. 1996. Introduction to quantitative genetics. $4^{\text {th }}$ Edition. Longman Group Ltd, United Kingdom.

FAOSTAT. 2012. Production of finger millet in Uganda during 1999- 2010. Statistic database of Food and Agricultural Organisation Publications, Rome, Italy.

IBPGR. (International Board for Plant Genetic Resources) 1985. Descriptors of finger millet (Eleusine coracana (L.) Gaertn). IBPGR Secretariat, Rome, Italy: pp. 20 
IRRI, 1996. Standard Evaluation System for rice $4^{\text {th }}$ Edition; IRRI, INGER Genetic Resources Center, Manila, Philippines.

Johnson, H.W., Robinson H.F. and Comstock, R.E. 1955. Genotypic and phenotypic correlations in soybean and their implication in selection. Agronomy Journal 47:477-483.

Kumar, A., Misra, S.C. and Singh, B.P.S.,1985. Variability and correlation studies in triticale. Journal of Maharashtra Agricultural University 10:273-275.

Kumar, K. and Pande, A. 2010. Study of genetic diversity in finger millet (Eleusine coracana L. Gaertn) Using RAPD markers. African Journal of Biotechnology 9:4549-4549. Available online: http://www.academicjounals. org/AJB (date accessed: 23/11/2011).

Lenka, D. and Mishra,B. 1973. Path coefficient analysis of yield in rice varieties. Indian Journal of Agricultural Science 43:376-369.

Lenne, J.M., Takan, J.P.Mgonja, M.A. Manyasa, E.O.,Kaloki, P., Wanyera, N., Okwadi, J., Muthumeenakshi, S., Brown, A.E., Tamale, M. and Sreenivasaprasad, S. 2007. Finger millet blast management: A key entry point for fighting malnutrition and poverty in East Africa. Outlook on Agriculture 36:101-108.

Lule, D., Tesfaye, K.,Fetene, M. and De Villiers, S. 2012. Inheritance and association of quantitative traits in finger millet (Eleusine coracana Subsp.coracana) landraces collected from Eastern and Southern Africa. International Journal of Genetics 2:12-21.

Mackill, D.J. and Bonman,J.M. 1992. Inheritance of blast resistance in near- isogenic lines of rice. Phytopathology 82:746-749.

National Research Council, USA. 1996. Finger millet. P. 39-57. In: Lost crops of Africa: volume I: Grains. Board on Science and Technology for International Development. National Academy of Sciences, National Academy Press, Washington D.C.

Oduori, C.O.A. 2008. Breeding investigations of finger millet characteristics including blast disease and striga resistance in western Kenya. Unpublished PhD Thesis, University of Kwazulu Natal, Pietermaritzburg, South Africa.

Okwadi, J. 2007. Importance and characteristics of finger millet processing Uganda. pp. 102-111. In: Mgonja, M.A., Lenne, J.M. Manyasa, E. and Sreenivasaprasad, S. (Eds). Proceedings of the first international finger millet stake-holders workshop, projects R8030 \& 8445, UK Department for International Development - Crop Protection Programme held on $13^{\text {th }}-14^{\text {th }}$ September 2005 at Nairobi, Kenya.

Payne, R.W., Murray, D.A., Harding, S.A., Baird, D.B. and Soutar, D.M. 2009. An introduction to GenStat for Windows $\left(12^{\text {th }}\right.$ Edition). VSN International, 5 The Waterhouse, Waterhouse Street, Hemel Hemstead, UK.

Prasad Rao, K.E., de Wet, J.M.J., Gopal Reddy, V. and Mengesha, M.H.1994. pp. 331-345. In: Riley, K.W., Gupta, S.C., Seetharam, A. and Mushonga, J.N. (Eds.). Diversity in the small millets collections at ICRISAT, Advances in Small Millets, International Science Publisher, New York, USA. 
Quynh, L.V. and Bong. B.B. 1999. Study of durable resistance of rice varieties to blast disease in the Mekong delta of Vietnam. Omonrice 7:9-14.

Robinson, H.F., Comstock, R.E. and Harvey, P.H. 1949. Estimates of heritability and degree of dominance in corn. Agronomy Journal 41:353359.

Singh, P. and Narayanan, F. 1993. Biometrical Techniques in Plant Breeding. Kalyani publishers, New Delhi, India.

Singh, R.K. and Chaundhary, B.D. 1977. Biometrical Methods in Quantitative Genetics Analysis. Kalyani publishers, New Dehli, India. pp. 304.

Takan, J.P., Akello, B., Esele, P., Manyasa, E.O., Obilana, A., Audi, P.O., Kibuka, J., Odendo, M., Oduori, C.A., Ajanga, S., Bandyopadhyaya, R., Muthumeenakshi, S., Coll, R., Brown, A.E., Talbot, N.J. and Sreenivasaprasad, S. 2004. Finger millet blast pathogen diversity and management in East Africa: a summary of project activities and outputs. International Sorghum and Millets Newsletter 45:66-69.

Torres, C.O. and Teng, P.S. 1993. Path coefficient and regression analysis of the effect of leaf and panicle blast on tropical rice yield. Crop Protection 12:296-302.

Wanyera, N.M.W. 2007. Finger millet (Eleusine coracana (L) Gaertn) in Uganda. pp. 1-9. In: Mgonja, M.A., Lenne, J.M., Manyasa, E. and Sreenivasaprasad, S. (Eds). Proceedings of the first international finger millet stake-holders workshop, Projects R8030 and 8445, UK Department for international development - crop protection programme held on $13^{\text {th }}-14^{\text {th }}$ September 2005 at Nairobi, Kenya.

Wheeler, B.E.J. 1969. An introduction to plant disease. John Wiley and Sons Ltd., London, p. 301. 